DOI: 10.2478 /ausp-2020-0007

\title{
"Like Ireland, Hungary Had Her Struggles for Freedom:" Cultural and Diplomatic Links between Interwar Ireland and Hungary
}

\author{
Lili ZÁCH \\ Maynooth University (Ireland) \\ Department of History \\ lili.zlil@gmail.com
}

\begin{abstract}
The interwar years in Ireland were marked by the widening of international relations following the newly independent Irish Free State's entry to the League of Nations in 1923. This paper aims to provide insights into a lesser-known part of Irish diplomatic history, focusing on how, besides Geneva, Dublin also became significant as a meeting point with Central European small states from the mid-1920s. It will trace how the foundation of the Honorary Consulate of Hungary in Dublin demonstrated Irish interest in widening economic relations and furthering cultural connections with Central Europe, even if honorary consulates traditionally fulfilled primarily symbolic purposes. Based on so far unpublished archival materials and press records, this article will assess cultural and diplomatic links cultivated under the consulate of Hubert Briscoe, highlighting the significance of independence and Catholicism as a perceived connection between Irish and Hungarian national identities. Ultimately, this article argues that Irish images of East-Central Europe may add to our current understanding of Irish nationalism in the first decades of Irish independence.
\end{abstract}

Keywords: Ireland, Hungary, diplomatic history, cultural nationalism

\section{Introduction}

Before the Great War, many Irish nationalist intellectuals, revolutionaries, politicians, businessmen, and journalists had acquired personal experience regarding Habsburg Central Europe. Given the perceived similarity of circumstances, the pre-war perceptions of Irish commentators often influenced their reactions to the transformation of the political order and identities even after the dissolution of the Austro-Hungarian Empire in 1918. The complexity and controversial nature of Irish national identity in the early twentieth century has been noted in Irish 
historiography (Boyce 1995, Garvin 2005, Hutchinson 1987). Language and religion were significant factors in defining national identities, but Irish cultural nationalists such as Douglas Hyde - Protestant Gaelic scholar, founder of the Gaelic League in 1893 and first President of Ireland - proposed "a mobile vision of the nation interacting with the wider world" (Hutchinson 1987, 483). Therefore, the Irish language heritage by no means excluded awareness of other nations fighting similar struggles for emancipation in the late nineteenth/early twentieth centuries.

The lack of extensive research on the link between Ireland and East-Central Europe may be explained by the absence of direct diplomatic links between Ireland and the small successor states of the Austro-Hungarian Empire before the mid1970s. Due to the financial constraints on the Department of External Affairs (and after 1945 due to the emergence of the Cold War), Ireland and the successor states of Austria-Hungary did not establish full bilateral diplomatic relations until the second half of the twentieth century (with Austria in 1951, with Czechoslovakia in 1975, and with Hungary in 1976). Nevertheless, the lack of specific secondary sources does not mean a lack of awareness, interest, or contact: diplomatic records indicate the contrary. Irish businessmen and intellectuals were more than eager to get acquainted with the newly independent small states of Central Europe in the aftermath of the First World War. Some of them, like journalist-turned-businessman Hubert Briscoe, had an interest in Central/Eastern Europe that went beyond the war years. Others sought new opportunities that they hoped would benefit the emerging young Irish economy as well as their own private businesses.

After a short introduction about the formative years of the young Irish diplomatic service, the present article will provide an insight into the foundation and the main activities of the Hungarian Honorary Consulate in Dublin, outlining Irish cultural connections with Hungary, with special attention to the mutual interest and connections established through the Fourth World Scout Jamboree (1933), the Irish-Hungarian Friendship Tour (1937), and the Thirty-Fourth Eucharistic Congress (1938).

\section{The Irish Free State and the Wider World}

After the establishment of the Irish Free State following the years of destruction during the War of Independence (1919-1921) and the subsequent Civil War (19221923), Irish politicians and diplomats hoped that the newly independent state would develop beneficial relationships with other small states in Europe. The Free State had to rely on a limited network of bilateral relations in the 1920s, and links with Central Europe were particularly restricted, reduced to honorary consulates and consulates in Dublin, not employing official diplomats but mostly businessmen who applied voluntarily to fill those positions. Although the young diplomatic 
service still faced financial problems, primary evidence indicates that the existence of consular links with Austria, Hungary, and Czechoslovakia should not be ignored.

From the mid-1920s, after the transitory period of what is labelled in historiography as an "administrative vacuum” (Nolan 2004, 21), Irish representatives were sent to great powers such as Germany and the United States of America, in addition to receiving the representatives of small nations like Austria, Hungary, or Czechoslovakia. Thus, even though the Irish diplomatic presence in Europe was quite small at the time, it was a fact that "the major Continental powers kept a consular and diplomatic presence in Dublin” (Keogh 1988, 24). In the early years of independence, the founders of the new state "sought to change not only the way the Irish interacted with the outside world, but also the way the rest of the world perceived the Irish" (Keown 2000, 42). That is to say, by drawing primarily on the Free State's multiple identities, connections were established with Europe, the Irish diaspora across the globe, and also the Commonwealth.

Establishing an efficient foreign service was of key importance in order to convince the sceptics at the Department of Finance that the Department of External Affairs was worthy of being an independent department on its own. The existence of the Irish diplomatic service, therefore, was "more than a symbol of independence and sovereignty" (Keogh 1988, 19). Among others, the Department of External Affairs played a key role in establishing the status of the Free State both within the League of Nations and the British Commonwealth. The League of Nations, which the Irish joined in September 1923, provided the framework for Irish diplomats and shaped Irish foreign policy in the interwar era, both under the rule of Cumann na nGaedheal (1923-1932) and Fianna Fáil (after 1932). It is noteworthy that under both administrations Catholicism was a common ground that the Department and the independent Irish Free State wished to count on when establishing further contacts. Certainly, the enthusiasm of the Secretary of the Department of External Affairs (1923-1946), Joseph P. Walshe, “for Catholic Europe” was a major contributing factor in this (Nolan 2004, 23).

\section{The Honorary Consulate of Hungary in Ireland}

Despite the fact that official diplomatic contact between Ireland and Hungary was established in the 1970s, Irish archival records indicate that the relationship dates back to the interwar period. As early as December 1923, the Hungarian Kingdom sought permission to nominate an honorary consul in Dublin, when the Hungarian representative in London enquired at the British Foreign Office if there were any objections to the appointment of a Hungarian consul in Dublin; there were none (National Archives 1923). Progress was made in 1925 when the Hungarian Charge d'Affaires in London, Jenő Nelky, checked with Irish High Commissioner James 
McNeill if Dublin-born stockbroker Hubert Briscoe was suitable. The Hungarians expressed a preference for "a man who has no strong political affiliations, and for choice a businessman of good standing who would like to supplement a solid civic status with a little consular dignity," and Briscoe was found to be just "the sort of man" the Charge d'Affaires wanted (National Archives 1925). Hungarian Governor Admiral Miklós Horthy appointed the well-known Dublin stockbroker (also holding the title of government broker) Honorary Royal Hungarian Consul in December 1925 (National Archives 1926).

Throughout the first half of the twentieth century, Briscoe had revealed an ongoing interest in East-Central Europe, first as a Catholic journalist before the First World War and then, from the mid-1920s, as the Honorary Consul of Hungary in Ireland. His first trip to the southern parts of the Dual Monarchy took place in May 1904, when he was "privileged to join an organized party of literary folk who were bound for a few weeks" excursion to Dalmatia and Bosnia-Herzegovina (Irish Independent 2 July 1904). His writings went beyond the format of travelogues, as illustrated by his article published in February 1908, eight months before Austria-Hungary annexed Bosnia-Herzegovina. Briscoe had already sensed the gravity of the political and possibly military conflict in the Balkans, claiming that it had the potential to lead to further complications (Irish Independent 28 February 1908). Nevertheless, even after the Austro-Hungarian annexation of Bosnia-Herzegovina, he still adhered to his conviction that the Habsburgs "had done magnificent work" since Bosnia's occupation in 1878. He saw the events of 1908 not as a sign of aggression by a great power, rather "a preliminary to the granting of a complete measure of autonomy to the Bosnian people," similar to the idea of the Irish Home Rule (Irish Independent 14 October 1908). Briscoe underlined that "if ever any great Power has earned the right to sovereignty over a smaller nation, Austria-Hungary, by her enlightened policy and sympathetic rule, has surely vindicated her present claims in the case of Bosnia. Indeed the whole latter-day history of the province stands as a striking object lesson to the countries nearer home" (Irish Independent 14 October 1908).

After the establishment of the Hungarian Honorary Consulate in December 1925, the British connection remained significant throughout the interwar period even though the Irish administration (both under William T. Cosgrave and, after 1932, Éamon de Valera) placed considerable emphasis on the Irish Free State's sovereignty. This was also illustrated by the interest Britain-based Hungarians (such as Baron Iván Rubido-Zichy, Hungarian representative in London) expressed about visiting Dublin (Irish Independent 10 August 1908).

Archival records indicate that while Briscoe appeared to have taken his duties seriously, the Irish Department for External Affairs (or its effective person in charge, Secretary Joseph P. Walshe) did not seem to have reciprocated Briscoe's enthusiasm, resulting in a troublesome relationship between the Consulate and the Department at times. For instance, following the visit of a Hungarian delegation for the Inter- 
Parliamentary Union in Dublin in July 1930, Briscoe expressed his disappointment with the Department for not having informed him about the arrival of Hungarian visitors in Dublin. The Irish Independent's representative highlighted a mutual interest between the Hungarians and the Irish, emphasizing nationalist politician Arthur Griffith's former "interest in the Hungarian policy, and the use he made of it in the early days of Sinn Féin" (Irish Independent 21 July 1930). Of course, the paper was referring to Griffith's The Resurrection of Hungary (1904), possibly one of the most influential Irish studies of the political history of Hungary. Having grown disillusioned with the Home Rule movement and mainstream Irish nationalism, Griffith proposed "a middle way between parliamentarism and republicanism” in order to achieve Irish constitutional independence and economic self-sufficiency by non-violent, political means based on the model of a Dual Monarchy (Maye 1997, 97, Haglund and Korkut 2015, 49 and 55).

The Irish Independent's report was also significant due to the fact that Briscoe admitted to having learnt the news about the Hungarian delegation from the press and wished to officially protest that he had not been notified of the visit. Therefore, he asked Department of External Affairs Secretary Walshe if it was "the settled policy of [the] department that the Honorary Consul for Hungary should be ignored when Hungarians came to Dublin under government auspices, or on other kindred occasions. If so," warned Briscoe, "it will be necessary for me to consider my position” (National Archives 1930a). Eventually, Briscoe accepted Walshe's suggestion to "have a little chat," after which they were to let the matter rest (National Archives 1930b). Nonetheless, another confidential letter from Briscoe to Walshe three years later in 1933 signified that their agreement was not a lasting one. The Consul reminded the Secretary that he had "for a long time, been very dissatisfied with the recognition given to Hungary in this country" (National Archives 1933a). He emphasized that it was his duty to "see that the honour and prestige of Hungary was maintained, and that [he] should do everything that was possible in Ireland for the advancement of Hungarian interests," stressing that in this he had "had no assistance" from the Department of External Affairs (National Archives 1933a). And although he received "much kindness" from other foreign representatives in Dublin, the Department had completely ignored his Consulate,

and Hungary [had] been left out in the cold on many occasions when she was entitled to be brought into at least the same prominence as other countries of perhaps less international importance. In the circumstances I fear that the only course left open for me is to recommend the Hungarian Government to abolish the Consulate in Dublin altogether, but before doing so I would like to know officially what is to be the future attitude of your Department towards it. (National Archives 1933a) 
In Walshe's absence, Assistant Secretary John Joseph Hearne replied, and his "kind remarks" seemingly convinced Briscoe not to "proceed any further in the matter" (National Archives 1933a).

\section{Irish-Hungarian Cultural Links during the Interwar Years}

Due to his background in business and finance, Briscoe's priorities as Honorary Consul of Hungary lay with mapping out possible economic contacts between the two states. However, under his term, cultural relations were also fostered between Hungary and Ireland. These cultural events and meetings were covered widely in Irish newspapers as well. For instance, minor as it may seem, the Fourth World Scout Jamboree that was organized in Hungary in August 1933 (the first international gathering of the scouts took place in 1920) still offered a great opportunity for both the youth and the educational politicians of Ireland and Hungary to learn about each other's cultures and customs (and of altogether forty-six nations). The Irish Independent recognized Catholicism as the main link, highlighting the significance of religious events such as the High Mass. The overall importance of the event was also indicated by the fact that the Chief Scout of Hungary and the Jamboree Camp Chief was Pál Teleki, former prime minister (1920-21; 1939-41) and founder of the Christian National Party (Irish Independent 31 July 1933). Afterwards, the Commissioner of the Irish Free State Scouts, G. S. Childs, informed the Irish Department of External Affairs of the success of the Irish trip. The Hungarian papers, elaborated Childs, referred to the Irish boys as "the pets of the camp', a tribute which speaks for itself" (National Archives 1933b). He emphasized that during his conversations with

prominent Hungarians, including Foreign Office officials, deputies, and newspaper men, I was pleased to find that they had a great sympathy with the Irish Free State, and wished our land prosperity and peace. They were of the opinion that Ireland and Hungary were in pre-war days working under similar conditions for the same end, and now that both countries control their own destinies, they were naturally anxious to learn as much about our country as possible. I feel that in their own small way the Irish Scouts materially helped to enhance the good name of our country at this great event. (National Archives 1933b)

In the words of the Lord Mayor of Dublin, Alfred Byrne, the Irish Scouts had enhanced the good name of their country in Hungary, and later a distinguished Hungarian diplomat informed him that the Scouts had been the finest ambassadors Ireland ever sent to Hungary (Irish Press 30 July 1937). Therefore, given that the 
Irish Government did not appoint official representatives in interwar Hungary, the presence of Irish scouts in an international context should not be dismissed.

Furthermore, what started as a university exchange programme in 1936 between Irish and Hungarian students, turned eventually into an "Irish-Hungarian Friendship Tour" with the participation of Briscoe and other distinguished Irish personalities. The watershed moment was John Vágó's (representative of the National Union of Hungarian Students in Great Britain) arrival in Dublin to initiate a series of IrishHungarian tours. Vágó followed up the visit of Irish university students to Hungary in the summer of 1936 and the return visit to Ireland of Susan Kemeny (Budapest University) in December 1936 (Irish Press 22 February 1937). Kemeny, representative of the National Union of Hungarian Students in England, was engaged with a peace propaganda tour among the universities of Europe, including Queen's University in Belfast. When she arrived in the Free State in December 1936, she took part in a broadcast from Radio Athlone and attended a concert arranged in her honour by Dublin students. The programme was entirely in Irish and Hungarian and was also attended by the Lord Mayor of Dublin (Irish Independent 11 December 1936). When Kemeny returned to Dublin in May 1937, she was invited to talk at Trinity College Dublin, where she gave a speech on 3 June and elaborated on how "like Ireland, Hungary had her struggles for freedom" (Irish Press 4 June 1937). She also attended a luncheon organized by the League of Nations Society of Ireland, where she introduced Hungary as "the last outpost of Christianity and defence of European civilisation in the East" (Irish Press 12 May 1937), a metaphor often used by Irish intellectuals, particularly Edward J. Coyne (Studies: An Irish Quarterly Review 1929, 1930, 1932) to describe the significance of Ignaz Seipel and Austrian Christian socialists. Kemeny emphasized the closeness of the Irish and Hungarian nations both "in thought and spirit", with their history "filled with the same idea the striving for independence and the love of freedom" (Irish Press 12 May 1937). In June 1937, she also addressed the Dublin Rotary Club, representing the Hungarian Congress Bureau, referring to Arthur Griffith, and the historical significance of selfsufficiency for Hungary as well as for Ireland (Irish Press 12 May and 29 June 1937).

The initiative for the Hungarian-Irish Friendship Tour was supported by Hubert Briscoe in addition to Tomás Ó Faoláin, editor of the National Student, independent politician and businessmen Frederick Maurice Summerfield, Lord Mayor of Dublin Alfred Byrne, and violinist and academic Walter Starkie. Starkie was professor of Spanish and lecturer in Italian literature at Trinity College as well as director of the Abbey Theatre, Ireland's National Theatre. Based on his experiences in Central/ Eastern Europe, Starkie wrote literary travelogues first published in 1929 under the title Raggle-Taggle: Adventures with a Fiddle in Hungary and Roumania (Sagarra 2012). Starkie expressed admiration for Hungarian culture and music; he did not, however, draw any parallels with Ireland. The only reference to contemporary Ireland was when he mentioned that the owner of the Hotel English Queen (without 
specifying the exact location) did not understand the distinction between being English or Irish as he had not met an Irishman before (Starkie 1933, 147). Starkie also noted that as far as the perception of the English was concerned, Lord Rothermere, who advocated the Hungarian case in the Daily Mail, was held in the highest esteem in Hungary, while in Ireland he and his newspaper were mostly criticized in relation to their support for the Hungarians. He argued that even the "hovels of the Gypsies" echoed from the cry "Lord Rothermere: éljen! Éljen! [Long Live]" (Irish Independent 3 October 1929). British newspaper magnate Lord Rothermere was known for his campaign in the British Daily Mail, launched on 27 June 1927 with an article entitled "Hungary's Place under the Sun," supporting the small state's irredentist claims (Boyce 2011). He also founded the Hungarian Revisionist League, which Hungarian Prime Minister István Bethlen saw as the "wrong kind of revision," meaning ethnic revision as opposed to the restoration of the historical integrity of St Stephen's nation (Cartledge 2009, 124-125).

The significance of the Irish-Hungarian Friendship Tour was also illustrated by Vágó's statement that his interest in Ireland stemmed from the fact that "there was much in common between the two countries in their history of oppression," referring to the impact of Arthur Griffith in Hungary (Irish Press 25 February and 30 March 1937). Hungarian sporting success proved to be the centre of common interest in the interview, together with the popularity of football in the country. The visits by the Hungarian football team to Ireland were quite frequent and well documented; in the late 1930s, the teams were often received by dignitaries such as Taoiseach (Prime Minister) Éamon de Valera, the Lord Mayor of Dublin Alfred Byrne, and Honorary Consul of Hungary, Hubert Briscoe. Great significance was attributed to these matches since they added another dimension to the existing consular or cultural contact between Ireland and Central Europe (Irish Independent 7 December 1936).

Led by Briscoe, the Irish-Hungarian Friendship Tour, which took place in the period of 10-31 July 1937, attracted attention both in Ireland and Hungary. The itinerary included Munich, Vienna, Budapest, Venice, Geneva, and Paris (Irish Press 25 February 1937). The party of sixty people also included Walter Starkie, Padraig Ó Caoimh, and Professor J. T. Wigham (Irish Press 31 May 1937). Given its popularity, a second tour was planned for August 1938: the Lord Mayor of Dublin, Alfred Byrne, spoke of his intentions to visit Hungary and participate in the Second Irish-Hungarian Friendship Tour on 13 August as part of a sixteen-day trip, calling the first one a "remarkable success." For the second Tour, the plan was to start in Cologne, Germany, reaching Budapest for St Stephen's holiday on 20 August, then on the way back stopping in Vienna, Innsbruck, and Munich - interestingly, not making any references to the fact that Germany had been under Nazi rule since 1933. Briscoe was named the patron of the tour again, and enquiries were directed to the Honorary Secretary of the Second Irish-Hungarian Friendship Tour, Suzanne Kemeny (Connaught Telegraph 2 April 1938). 
Notwithstanding the generally positive feedback, Gertrude Gaffney of the Irish Independent was less enthusiastic about the tour. She was known for her zealously Catholic, pro-Franco reports on events during the Spanish Civil War, which tended to go off on a tangent (Maume 2012). In her article in the Irish Independent, she claimed that "the less you know about other countries and the less contacts you have with other peoples the more likely you are to remain at peace with them" (Irish Independent 5 March 1937). This was due to the fact that she had been disillusioned in her friendships with Central/Eastern Europeans, referring to them as always demanding more than what she could offer. Thus, while calling the plan for the friendship tour "an admirable idea," what she objected to was "describing it as a reciprocal tour until the Hungarians in equal numbers, or very nearly as many at any rate, have arranged to come here, and I doubt if that will ever come to pass" (Irish Independent 5 March 1937). As an alternative, she suggested that efforts rather be put towards attracting American tourists to Ireland. Interestingly though, Gaffney did not seem to be aware of the fact that the whole idea behind the Irish-Hungarian Friendship Tour was initiated on the Hungarian side, following the aforementioned visits of Susan Kemeny to Dublin. Apart from Gaffney's criticism, the general opinion of the Irish relationship with Central European small states, however small in scale, was overwhelmingly positive.

In order to increase the popularity of Hungarian culture in Ireland, several programmes were attributed to Hungarian classical and folk music on the programme of Radio Athlone. Trinity Professor Walter Starkie's contribution was significant in this regard, given his documented interest in Hungarian music and culture in general - "A Hungarian Hour," which aired in May 1937 and included comments from Susan Kemeny and Tomás Ó Faoláin (Irish Press 18 May 1937). However, it was Hubert Briscoe who managed to highlight the overarching significance of Hungarian culture and history for Ireland when he

welcomed the broadcast, because it [was to] give to the Irish people an opportunity of learning something about the country, which he had the privilege of representing. The history of Hungary, like that of Ireland, was one of trouble, and there was the same struggle for independence of language, ideas and culture. They in Ireland had much in common with Hungary and much to learn from her, and it was but natural that there should be mutual interests in the developments that had resulted from the pursuance of similar policies. (Irish Press 19 May 1937)

Undoubtedly, the Irish image of interwar Hungary had been shaped by several factors, including, most importantly, the Catholic perspective of the majority of commentators and the critical attitude to British policies regarding Ireland. In the late 1930s, it became more and more regular to have Hungarian voices heard in 
Ireland - whether on the programme of Radio Éireann, on the pages of major Irish dailies, or in person at different scenes of Dublin social, intellectual, and religious life (Irish Press 28 September 1938). For instance, Suzanne Kemeny, who was, stressed the Irish Independent, "well known in Dublin," spoke as part of a special broadcast from Radio Éireann about the Eucharistic Congress in Budapest (Irish Independent 27 May 1937).

The impact of Catholicism on Irish perceptions had not faded by any means by 1938, as illustrated by the strongly Catholic and conservative nationalist Constitution of 1937. Moreover, when the Thirty-Fourth Eucharistic Congress took place then in Budapest in May 1938, the event turned out to be more than simply symbolic for the Irish delegation, particularly in view of the fact that in 1932 the Eucharistic Congress was organized in Dublin with huge success for the newly elected Éamon de Valera, consolidating not only the power of Fianna Fáil but also the significance of Catholic nationalism in the Irish Free State.

Eugenio Pacelli (later Pope Pius XII) served as papal legate in Budapest in 1938 and offered the admonition at the Hungarian Eucharistic Congress. Similar to the theme of many Catholic Irish writers at the time, he praised the strength of Hungarians defending the Christian civilization. In 1938, this could stand for opposition against Nazism or, even more so, communism (Irish Press 30 May 1938). The peculiarity of the Eucharistic Congress is indicated by the fact that it was organized only a few months after the Austrian Anschluss (March 1938) and before the Munich Agreement (September 1938) and the First Vienna Award (November 1938), all of which contributed to the total transformation of the political status quo in Central Europe.

The Hungarian Eucharistic Congress, held between 25 and 29 May 1938, was attended by, among others, an Irish delegation of 110 members, organized by the Irish Catholic Truth Society (Irish Independent 26 January 1938). "Hungary has close affinities with Ireland," explained the organization: "it is Catholic through and through and, like Ireland, wrested its independence from the invader" (Irish Press 5 March 1938). Although the Irish delegation was small, it represented, claimed the Catholic Truth Society, "a gesture of brotherhood with the people of Hungary” (Irish Press 30 May 1938). The Irish Government was represented by An Tánaiste (Deputy Head of Government) Sean T. O’Kelly; Baron Zsigmond Perényi, Steward of the Holy Crown of St Stephen, was quoted as saying that "Hungarians felt warm sympathy with Ireland, because they had so many things in common," for they had both kept the faith for centuries and had also suffered greatly for it, adding that the "Wild Geese" were among those who fought for the liberation of Buda from the Turks in 1686 (Irish Press 6 June 1938), pointing to the flight of Catholic Irish soldiers to Europe between the sixteenth and eighteenth centuries. Most importantly, the paper drew a comparison between Hungary's mission in 1686 and that of 1919, when "Hungarians were again called upon to 
protect Christian Europe from a peril even worse than the Turks - the Bolsheviks" (Irish Press 6 June 1938). Besides the Irish military presence, it is noteworthy that Catholic Irish students had also migrated to the Continent during the same period when the Penal Laws disempowered the Catholic and Dissenter population in Ireland (Power and Pilný 2014, 4).

The Special Correspondent of the Irish Independent, Gertrude Gaffney, was in Budapest for the duration of the whole event to report on the Eucharistic Congress. She pointed to the disappointment of the Hungarian organizers that no visitors were arriving from Germany or Austria, "both big Catholic populations" (Irish Independent 24 May 1938). A month before the Eucharistic Congress took place in Budapest, the aforementioned John Vágó, representative of the Universities' Sub-Committee of the Congress, had visited the offices of the Irish Catholic Truth Society. Among others, Vágó discussed with an Irish Press reporter whether Hitler was to permit Austrian Catholics to attend the Eucharistic Congress, which was officially barred to German Catholics (Irish Press 5 April 1938). In her article, Gaffney quoted the Mayor of Budapest, Károly Szendy, speaking of the strong ties between Ireland and Hungary and of the similarity between Irish and Hungarian history (Irish Independent 27 May 1938). Moreover, Michael Nash, also writing for the Irish Independent a week prior to the event, had pointed to a number of issues that Ireland and Hungary were perceived to have in common. He directed the readers' attention to the "grievances as well as sympathies" in relation to fighting for nationhood, emphasizing that both had "suffered severely from religious persecution, and both are still struggling, with increasing success, to maintain the heritage of their national traditions and language" (Irish Independent 14 May 1938). As far as post-Trianon Hungary was concerned, Nash pointed to the loss of border provinces and as a result the strength of irredentism in the everyday life of “truncated modern Hungary” (Irish Independent 14 May 1938), an image used frequently to characterize post-Partition Ulster as well, within the Irish context.

\section{The Second World War and the Closure of the Consulate}

On the eve of the Second World War, there appeared to be an ongoing interest in maintaining economic links between Ireland and Hungary, as illustrated by a letter addressed to the Irish Minister for External Affairs written in French by Lucien Delorme. In his request for a diplomatic post as Honorary Consul of Ireland in Budapest, Delorme highlighted that he had been resident in Ireland for three years and owned a perfume factory in Budapest: hence his interest in furthering links between Ireland and Hungary in Budapest (National Archives 1938a). In his reply, Walshe informed Delorme that it was not the practice of the Irish Government to appoint Honorary Consuls abroad (National Archives 1938b). Therefore, the 
Department appeared to concentrate their efforts on developing diplomatic connections elsewhere. As Delorme applied at a time when trouble was brewing in East-Central Europe, not long before the Munich Agreement (30 September 1938) and the First Vienna Award (2 November 1938), the Department's response indicated that Central Europe may not have been the most favourable diplomatic or trading post for Ireland at the time. Nevertheless, despite the growing influence of the Axis powers on Hungary in the late 1930s, and even the Hungarian aggression towards her neighbouring small states, the outbreak of the Second World War did not result in any trouble regarding Irish-Hungarian relations. What is more, in December 1939, the Hungarian Consulate in Dublin was "raised to the status of Consulate-General, and Mr Hubert Briscoe, Honorary Consul, has been appointed Consul-General" (Irish Press 19 December 1939). The Cork Examiner added that Briscoe, being "a keen traveller," knew Hungary very well due to the fact that he had paid an annual visit to Hungary (Cork Examiner 6 January 1940). The British Government broke off relations with Hungary in April 1941; this, however, did not affect Irish-Hungarian links at this stage. In his letter to Walshe, dated 23 April 1941, Briscoe wrote: "I presume there is no need for me to do anything at this juncture" (National Archives 1941). It was only after the British declaration of war on Hungary on 7 December 1941 that Briscoe resigned from his post due to the irreconcilability of the declaration of war with his business interests in Britain. Communications were then carried through the Swedish Legation in London, who were in charge of Hungarian interests regarding Ireland (National Archives 1941). The position was not filled for almost half a century, and diplomatic connections were not established again until the 1970s.

\section{Conclusion}

This article has aimed to reveal a lesser-known aspect of Irish diplomatic and cultural history by providing an insight into how the foundation of the Honorary Consulate of Hungary in Dublin served to widen economic relations as well as further cultural connections between the Irish and Hungarian small states. Catholic Dublin stockbroker Hubert Briscoe filled the position of Honorary Consul of Hungary in Ireland between 1926 and 1941, and he became a key figure in promoting economic and cultural links between the two states, as the Irish Times had noted (29 December 1939). Interestingly, on the Irish side, even confidential archival records do not reveal much of the government's attitude towards these efforts, which remained symbolic throughout the first half of the twentieth century. Nevertheless, we have seen that many segments of Irish society, including businessmen, scholars, and public figures with cultural affiliations, expressed an ongoing interest in interwar Hungary. The Fourth World Scout Jamboree (1933), the Irish-Hungarian Friendship 
Tour (1937), and the Thirty-Fourth Eucharistic Congress (1938) demonstrated that the enthusiasm and efforts of the Irish public and Hungarian cultural initiatives outweighed the lack of attention from the Irish government. This article argued that the links established between Hungary and Ireland under Briscoe's term as Honorary Consul provided an additional dimension to Irish cultural nationalism during the first two decades of the Irish Free State, highlighting the persistence of the shared belief that "like Ireland, Hungary had her struggles for freedom."

\section{Works Cited}

Boyce, David George. 1995. Nationalism in Ireland. New York: Routledge. 2011. "Harmsworth, Harold Sidney, First Viscount Rothermere (1868-1940), Newspaper Proprietor." In Oxford Dictionary of National Biography. https:// www.oxforddnb.com/view/10.1093/ref:odnb/9780198614128.001.0001/odnb9780198614128-e-33718 (last accessed: 9 June 2020).

Cartledge, Bryan. 2009. Mihály Károlyi and István Bethlen, Hungary. London: Haus Histories.

Garvin, Tom. 2005. Irish Parties and Irish Politics from the $18^{\text {th }}$ Century to Modern Times. Dublin: Gill \& Macmillan.

Haglund, David G. and Umut Korkut. 2015. "Going against the Flow: Sinn Fein's Unusual Hungarian 'Roots'.” International History Review vol. 37, no. 1: 41-58.

Hutchinson, John. 1987. The Dynamics of Cultural Nationalism: The Gaelic Revival and the Creation of the Irish Nation State. London: Allen \& Unwin.

Keogh, Dermot. 1988. Ireland and Europe 1919-48. Dublin: Gill and Macmillan.

Keown, Gerard. 2000. "Creating an Irish Foreign Policy in the 1930s." In Irish Foreign Policy 1919-1966: From Independence to Internationalism, eds. Michael Kennedy and Joseph Morrison Skelly, 25-43. Dublin: Four Courts Press.

Maume, Patrick. 2012. “Gaffney, Gertrude.” In Dictionary of Irish Biography, eds. James McGuire and James Quinn. Cambridge University Press. http://dib.cambridge.org/viewReadPage.do?articleId=a3396 (last accessed: 9 June 2020).

Maye, Brian. 1997. Arthur Griffith. Dublin: Griffith College Publications.

Nolan, Aengus. 2004. Joseph Walshe: Irish Foreign Policy 1922-1946. Dublin: Mercier.

Power, Gerald and Ondřej Pilný, eds. 2014. Ireland and the Czech Lands: Contacts and Comparisons in History and Culture. Bern: Peter Lang.

Sagarra, Eda. 2012. “Starkie, Walter.” In Dictionary of Irish Biography, eds. James McGuire and James Quinn. Cambridge University Press. http://dib.cambridge. org/viewReadPage.do?articleId=a8262 (last accessed: 9 June 2020). 
Starkie, Walter. 1933. Raggle-Taggle: Adventures with a Fiddle in Hungary and Roumania. New York: E. P. Dutton.

\section{Archival Sources}

National Archives of Ireland, Department of Foreign Affairs. 1923 (December). "Letter from Devonshire to the Governor General T. M. Healy;" "Reply from Healy to the Duke;" "Proposed appointment of an [sic] Hungarian Consular Officer at Dublin, Consular Representation of Hungary in Ireland.” NAI DFA/319/49. S. 349028.

1925 (February). "Letter from High Commissioner for the Irish Free State, James MacNeill [sic] to Walshe;" "Letter from Walshe to McNeill, Consular Representation of Hungary in Ireland.” NAI DFA/319/49.

1926 (January). "Letter from Nelky to Chamberlain, the Secretary of State for Foreign Affairs;" "Letter from L. S. Amery to Healy, Consular Representation of Hungary in Ireland.” NAI DFA/319/49, T. 10355/3471/373 No. 3111.

1930a (July). "Private and Confidential Letter from Briscoe to Walshe, Consular Representation of Hungary in Ireland.” NAI DFA/319/49.

1930b (August). "Private and Confidential Letter from Briscoe to Walshe, Consular Representation of Hungary in Ireland.” NAI DFA/319/49.

1933a (August). "Confidential Letter from Briscoe to Walshe, Consular Representation of Hungary in Ireland.” NAI DFA/319/49.

1933b (August). "Letter from G. S. Childs, Esq, Co. Wicklow Boy Scouts' Association, to the Minister for External Affairs, Dublin.” NAI DFA 38/144.

1938a (August). "Application of Lucien Delorme of Budapest for Post of Irish Consul for Hungary.” NAI DFA 117/56.

1938b (September). "Letter from Walshe in English to Delorme Application of Lucien Delorme of Budapest for Post of Irish Consul for Hungary." NAI DFA 117/56, JAB/LL 117/56.

1941 (April). "Letter from Briscoe to Walshe;" "Copy of Telegram to the Hungarian Consul-General, Dublin.” NAI DFA 227/99.

\section{Newspapers and Journals}

Connaught Telegraph (1938)

Cork Examiner (1940)

Irish Independent (1904, 1908, 1929-1938 passim)

Irish Press (1937-1939)

Irish Times (1939)

Studies: An Irish Quarterly Review (1929, 1930, 1932) 